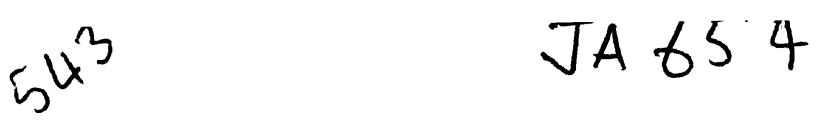

J. agric. Sci.. ('amb. (1987), 109, 519529

With 5 text-figures

Printed in Great Britain

\title{
Factors affecting growth and yield of short-duration pigeonpea and its potential for multiple harvests
}

\author{
BY Y.S. CHAUHAN, N. VENKA'TARATNAM AND A. R. SHELIDRAKE* \\ International Crops Research Institute for the Semi-Arid Tropics (I('RISAT'), Patancheru P.O. Andhra \\ Pradesh 502:324, India
}

(Revised MS. received 5 May 1987)

\section{SUMMARY}

Environmental and cultural factors that may limit the vield of short-duration pigeonpea were investigated over three seasons. Plants in the peninsular Indian environment at Patancheru grew less and produced less dry matter by first-flush maturity than at Hisar, a location in northern India where the environment is considered favourable for the growth of short-duration pigeonpea. However, with a similar sowing date in June, the mean seed yields of three genotypes, ICPL, 4, ICPL 81 and I('PI, 87, were very similar, at about $2 \cdot 3 \mathrm{t} / \mathrm{ha}$, in both environments. This was mainly due to the higher ratio of grain to above-ground dry matter at Patancheru. In addition to the first harvest, all genotypes showed a potential for two more harvests owing to the warm winters at Patancheru. The potential for multiple harvests was particularly high in ICPL 87 , which yielded $5 \cdot 2 \mathrm{t} /$ ha from three harvests in $1982-3,3.6 \mathrm{t} /$ ha from two harvests in $1983 \% 4$. and $4.11 /$ ha from three harvests in 19845 . 'The optimum plant population density at Patancheru was 25-35 plants $/ \mathrm{m}^{2}$ for ICPL 87 , but was higher for the other two genotypes.

At Patancheru, the total dry-matter and seed yield of first and subsecquent harvests were significantly reduced by delaying sowing beyond June. Generally. the second-and the third-harvest yields were lower on vertisol than on alfisol under both irrigated and unirrigated conditions.

The total yield of ICPL 87 from two harvests was far higher than that of a well-adapted medium-duration genotype BDN 1, grown over a similar period. The yield advantage was greater on the alfisol because of the better multiple harvest potential of this soil. The results of this study demonstrate that properly managed short-duration genotypes of pigeonpea may have considerable potential for increased yield from multiple harvests in environments where winters are warm enough to permit continued growth.

\section{INTRODUCTION}

In India, pigeonpea of about 6-9 months' duration has traditionally been grown as an intercrop. However, during the last decade it has been shown that genotypes of shorter duration, i.e. of about 4-5 months, when sown alone at the normal sowing time can give yields similar to or even higher than longduration genotypes in northern India (Saxena \& Yadav, 1975). Wallis et al. (1983) have also shown in Queensland, Australia, that properly managed short-duration and photo-insensitive genotypes of pigeonpea can produce yields of up to $8 \cdot 8 \mathrm{t} / \mathrm{ha}$, and that a ratoon crop can also be harvested. Thus by adopting pigeonpea of shorter duration, it appeared

* Present address: 20 Willow Road, London NW3, England. possible not only to increase the production of this pulse crop but also to create a greater flexibility in its use, which so far has been limited mainly to intercropping (Willey. Rao \& Natarajan, 1981).

Sole cropping of short-duration pigeonpea is already becoming popular in northern India, where it can be followed by a wheat crop (Kanwar, 1981). It was previously thought that short-duration pigeonpea was not suitable for peninsular India (Green et al. 1981), so research on pigeonpea in this environment has been limited mostly to mediumand long-duration types. There has been little attempt to identify the factors that limit the adaptation of short-duration pigeonpea. Such information would help to exploit its potential fully. The present investigations were, therefore, undertaken with the following objectives: $(a)$ to determine the 
Table 1. Details of experiments conducted in the 1982-3, 1983-4, and 1984-5 seasons

\begin{tabular}{|c|c|c|c|c|c|}
\hline Soil & $\begin{array}{l}\text { Date of } \\
\text { sowing }\end{array}$ & Treatments $\dagger$ & $\begin{array}{l}\text { Design } \\
\text { replications }\end{array}$ & $\begin{array}{l}\text { Plot } \\
\text { size } \\
\text { (m) }\end{array}$ & $\begin{array}{l}\text { Irrigation } \\
\text { (days after } \\
\text { sowing)* }\end{array}$ \\
\hline & & $1982-3$ season & & & \\
\hline Alfisol & 15 June & $\begin{array}{l}\text { Genotype: } \\
\text { ICPL 4, ICPL 81, ICPL } 87 \\
\text { Spacing }(\mathrm{cm}) \text { : } \\
50 \times 20,37.5 \times 10,30 \times 8,25 \times 6\end{array}$ & RBD, 3 & $6 \times 4$ & $\begin{array}{l}17,69,122 \\
157,182,220\end{array}$ \\
\hline Alfisol & 23 Aug. & $\begin{array}{l}\text { Genotype: } \\
\text { ICPL 4, ICPL 81, ICPL } 87 \\
\text { Spacing }(\mathrm{cm}) \text { : } \\
50 \times 20,37.5 \times 10,30 \times 8,25 \times 6\end{array}$ & RBD, 3 & $6 \times 4$ & $\begin{array}{r}0,53,88 \\
133,151\end{array}$ \\
\hline Entisol & $15 \mathrm{June}$ & $\begin{array}{l}\text { Genotype: } \\
\text { ICPL 4, ICPL 81, ICPL } 87 \\
\text { Spacing }(\mathrm{cm}) \text { : } \\
50 \times 20,37.5 \times 10,30 \times 8,25 \times 6\end{array}$ & RBD, 2 & $6 \times 4$ & $8,79,100$ \\
\hline Alfisol & 23 June & $\begin{array}{l}1983-4 \text { season } \\
\text { Genotype (SP): } \\
\text { ICPL 4, ICPL } 81, \text { ICPL } 87 \\
\text { Spacing (cm) (SP): } \\
50 \times 10,37 \cdot 5 \times 7 \cdot 5,30 \times 6 \\
\text { Irrigation (MP): } \\
\text { Irrigation, no irrigation }\end{array}$ & Split-plot, 3 & $6 \times 4$ & $140,180,211$ \\
\hline Vertisol & & $\begin{array}{l}\text { Genotype (SP): } \\
\text { ICPL } 81, \text { ICPL } 87 \\
\text { Spacing }(\mathrm{cm}) \text { (SP): } \\
50 \times 10,37.5 \times 7.5,30 \times 6 \\
\text { Dates of sowing (MP): } \\
28 \text { June, } 27 \text { July, } 22 \text { Aug. }\end{array}$ & Split-plot, 3 & $6 \times 4$ & \\
\hline $\begin{array}{l}\text { Alfisol } \\
\text { Vertisol } \\
\text { using }\end{array}$ & & $\begin{array}{l}1984-5 \text { season } \\
\text { Dates of sowing (SP): } \\
11 \text { June, } 25 \text { June, } 10 \text { July, } \\
25 \text { July }\end{array}$ & Split-plot, 3 & $6 \times 4$ & $\begin{array}{l}0,74,142,219 \\
255\end{array}$ \\
\hline ICPL 87 & & $\begin{array}{l}\text { Irrigation }(\mathrm{MP}) \text { : } \\
\text { Irrigation, no irrigation }\end{array}$ & & & $0,82,151,220,256$ \\
\hline $\begin{array}{l}\text { Alfisol } \\
\text { Vertisol }\end{array}$ & 15 June & $\begin{array}{l}\text { Genotype: } \\
\text { ICPL 87, BDN } 1\end{array}$ & RBD, 3 & $9 \times 6$ & $\begin{array}{l}0,70,138 \\
0,78,147\end{array}$ \\
\hline & \multicolumn{5}{|c|}{$\begin{array}{l}\text { Except for the experiment on entisol at Hisar all experiments were conducted at Patancheru. } \\
\text { * Calculated from first sowing date. } \\
+ \text { SP, subplot; MP, main plot. } \\
\ddagger \text { RBD, randomized-block design. }\end{array}$} \\
\hline
\end{tabular}

effect of location, soil type, and sowing date on the performance of short-duration pigeonpea, $(b)$ to study effects of plant population density, and $(c)$ to compare the performance of short-duration genotypes with a medium-duration genotype grown under near-optimum conditions to determine the potential of growing short-duration pigeonpea in peninsular India.

\section{MATERIALS AND METHODS}

Experiments were carried out in the three seasons of 1982-3, 1983-4 and 1984-5. In the first season, experiments were conducted at two locations in India, on an alfisol (Udic Rhodustalf) at Inter- national Crops Research Institute for the Semiarid Tropics (ICRISAT) Center, Patancheru $\left(17^{\circ} \mathrm{N}\right.$ $78^{\circ} \mathrm{E}, 545 \mathrm{~m}$ elevation), and on an entisol (Typic Camborthids) at Hisar $\left(29^{\circ} \mathrm{N} 75^{\circ} \mathrm{E}, 221 \mathrm{~m}\right.$ elevation). In the other two seasons, experiments were conducted at ICRISAT Center, Patancheru, on an alfisol and a vertisol (Typic Pellustert). The alfisol may hold less than $100 \mathrm{~mm}$ of available water, the entisol about $200 \mathrm{~mm}$ and the vertisol about 250 $\mathrm{mm}$ in the rooting zone. A basal dose of $100 \mathrm{~kg} / \mathrm{ha}$ of diammonium phosphate $(18 \% \mathrm{~N}, 20 \% \mathrm{P})$ was applied at Patancheru, and $20 \mathrm{~kg} / \mathrm{ha}$ of single superphosphate $(9 \% \mathrm{P})$ at Hisar. Seven experiments were conducted; the details are given in Table 1.

In all three seasons crops were protected from pod 
Table 2. Meteorological data for three planting seasons at Patancheru $(P)$ in peninsular India and one at Hisar $(H)$ in northern India

\begin{tabular}{|c|c|c|c|c|c|c|c|c|c|c|c|c|}
\hline Year & June & July & Aug. & Sept. & Oct. & Nov. & Dec. & Jan. & Feb. & Mar. & Apr. & May \\
\hline \multicolumn{13}{|c|}{ Total monthly rainfall (mm) } \\
\hline 1982-3 P & 193 & 155 & 69 & 180 & 59 & 12 & 0 & 0 & 0 & 13 & 0 & 47 \\
\hline $1982-3 \mathrm{H}$ & 48 & 106 & 101 & 0 & 0 & 0 & 9 & 23 & 2 & 3 & 108 & 32 \\
\hline $1983-4 \mathrm{P}$ & 87 & 211 & 305 & 287 & 132 & 1 & 17 & 5 & 1 & 21 & 31 & 0 \\
\hline 1984-5 P & 92 & 172 & 148 & 99 & 80 & 6 & 0 & 2 & 0 & 20 & 31 & 14 \\
\hline \multicolumn{13}{|c|}{ Mean maximum temperatures $\left({ }^{\circ} \mathrm{C}\right)$} \\
\hline 1982-3 P & 34 & 31 & 30 & 30 & 30 & 29 & 28 & 29 & 32 & 37 & 39 & 39 \\
\hline $1982-3 \mathrm{H}$ & 40 & 38 & 35 & 37 & 34 & 28 & 23 & 20 & 21 & 28 & 31 & 37 \\
\hline $1983-4 \mathrm{P}$ & 36 & 32 & 29 & 29 & 29 & 28 & 26 & 28 & 30 & 35 & 37 & 41 \\
\hline $1984-5 \mathrm{P}$ & 35 & 30 & 30 & 30 & 30 & 28 & 29 & 29 & 33 & 37 & 38 & 40 \\
\hline \multicolumn{13}{|c|}{ Mean minimum temperatures $\left({ }^{\circ} \mathrm{C}\right)$} \\
\hline $1982-3 \mathrm{P}$ & 24 & 24 & 23 & 23 & 22 & 20 & 17 & 13 & 17 & 20 & 23 & 25 \\
\hline $1982-3 \mathrm{H}$ & 27 & 27 & 26 & 22 & 18 & 12 & 6 & 5 & 6 & 13 & 16 & 22 \\
\hline 1983-4 P & 25 & 23 & 23 & 22 & 20 & 14 & 14 & 16 & 18 & 19 & 23 & 26 \\
\hline $1984-5 \mathrm{P}$ & 24 & 22 & 22 & 22 & 20 & 14 & 14 & 17 & 17 & 20 & 23 & $25)$ \\
\hline
\end{tabular}

Table 3. Number of days to flowering and maturity of three short-duration pigeonpea genotypes, 1982-3 ICPL $4 \quad$ ICPL $81 \quad$ ICPL 87

$50 \%$ flowering
Maturity
First flush
Second flush
Third flush

$50 \%$ flowering
Maturity
First flush
Second flush

$50 \%$ flowering
Maturity

borer (Heliothis armigera) infestation by spraying endosulfan (35 EC) at $21 /$ ha. The infestation of blister beetle (Mylabris pustiulata) was checked by removing the insects by hand.

Data for daily maximum and minimum temperatures (monthly averages) and total rainfall for the three growing seasons are given in Table 2.

\section{Growth analysis}

Plant samples for growth analysis were taken from an area of $3.2 \mathrm{~m}^{2} 63$ days after sowing in 1982-3, and at maturity in all locations and at all sowings. Also, a regular growth analysis was carried out at 20- to 40-day intervals to compare growth and yield of ICPL 87 with BDN 1 in the 1984-5 season. The area sampled each time ranged from 1.4 to $3.24 \mathrm{~m}^{2}$. In each sample, all the plants from the area sampled were counted and their fresh weights recorded. Then five randomly selected plants from this sample were used for further observations. Their fresh weights were taken and leaf areas measured on an automatic leaf area meter. Separated plant parts were oven-dried at $80^{\circ} \mathrm{C}$ for about $48 \mathrm{~h}$ and weighed. The total dry matter per unit area and per plant were then calculated.

\section{Yield harvests}

The seed yield estimates were from areas of 12 $18 \mathrm{~m}^{2}$. The crop was harvested when about $90 \%$ of its pods had matured. Up to three harvests were possible from the three short-duration genotypes in trials at ICRISAT Center. In order to maximize ratoon harvests, the first and second harvests were usually done by picking the mature pods by hand. However, the first harvest of ICPL 4 and ICPL 81 sown in June 1982 was done by cutting off the stems at about $60 \mathrm{~cm}$ from ground level. The harvested pods, or stem material with pods, were dried either in the sun or in a $40^{\circ} \mathrm{C}$ oven, and threshed. The moisture content of the grains weighed for yield 
(a)

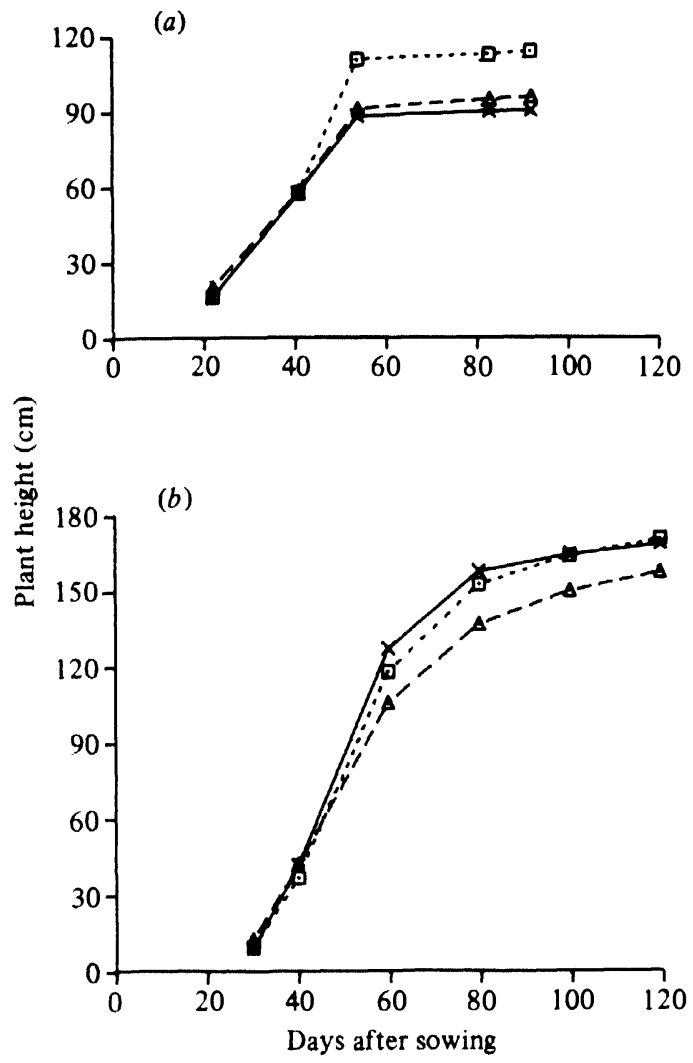

Fig. 1. Mean plant height of three short-duration genotypes, I(PL $+(x-x)$, ICPL $81 \quad(\square--\square)$ and ICPI, 87 $(\triangle-\Delta)$ in June sowing at $(a)$ Patancheru and $(b)$ Hisar, $1982-3$.

estimation was about $910 \%$. Harvest index was calculated as the ratio of seed yield to total aboveground dry matter. excluding fallen leaves.

\section{RESULTS}

\section{Location effects}

Phenology and crop growth

In the 19823 season at Patancheru, the June and August sowings of all three short-duration genotypes, ICPL 4, ICPL 81 and ICPL 87, flowered and matured about a month earlier than at Hisar (Table 3).

By maturity all three genotypes had grown taller at Hisar than at Patancheru (Fig. 1). The final height attained by the crop at Hisar was $160-170 \mathrm{~cm}$ and at Patancheru, 90-110 $\mathrm{cm}$ in the June sowing; and $60-70 \mathrm{~cm}$ in the August sowing at Patancheru (not shown in the Figure).

Plants grown at Hisar accumulated more dry matter than the plants from either sowing at Patancheru (Table 4). At Patancheru the June sowing produced more dry matter than the August sowing both at 63 days after sowing (DAS) and at maturity. The dry-matter production at 63 DAS and at maturity was greater for ICPL 87 than for the other genotypes. The August-sown plants at Patancheru accumulated less leaf area than those sown in June (Table 5). The leaf area index attained by ICPL 87 at 63 DAS was more than that for the other two genotypes. It also retained a greater leaf area index at first-flush maturity.

\section{Seed yield at the first harvest}

The mean first harvest yield in the June sowing at Patancheru was similar to that at Hisar, about $2 \cdot 3$ $t /$ ha (Table 6). Yields were lowest for the August sowing at Patancheru. There were significant genotypic differences in yield. ICPL 87 gave the highest yield at Hisar and in the August sowing at Patancheru, whereas in the June sowing at Patancheru ICPL 81 gave the highest yield. ICPL 4 gave the lowest yield in all trials.

Mean harvest indices for the June and August sowings at Patancheru for the first harvest were higher than at Hisar ('Table 7). Significant genotypic differences in harvest index occurred only for the crop sown in June at Patancheru.

\section{Seed yield in subsequent harvests}

At Patancheru, the crops sown in June produced two additional flushes of flowers, and the August sowing only one. The number of days to maturity of the second and third flushes are also given in Table 3. The second harvest yields at Patancheru were as high as $2 \mathrm{t} / \mathrm{ha}$ for the June sowing and $0.96 \mathrm{t} / \mathrm{ha}$ for the August sowing in ICPL 87. These were significantly higher than for the other two genotypes (Table 6). In the June sowing at Patancheru, the second harvest yield of ICPI 87 may not be directly comparable with the other genotypes since this was harvested by ratooning rather than hand-picking. However, considerable regrowth had occurred for ICPL 81 before it produced a second harvest, which is indicated by the longer time taken by this genotype to reach second-flush maturity (Table 3 ). In a comparison of the effects of ratooning and handpicking, this genotype gave about $17 \%$ lower second harvest yield with ratooning (unpublished results). The June sowing at Patancheru produced a third flush where yield of ICPL 87, at about $1 \mathrm{t} / \mathrm{ha}$, was significantly higher than that for the other two genotypes. The total yield from three harvests was as high as $5.2 \mathrm{t} /$ ha for ICPL 87 , significantly higher than for the other two genotypes. In the August sowing, the total yield of two harvests of ICPL 87 was also significantly higher than for the other two genotypes. 
Table 4. Total dry matter ( $t /$ ha) of three short-duration pigeonpea genotypes 1982-3

\begin{tabular}{|c|c|c|c|c|c|c|}
\hline \multirow[b]{3}{*}{ Genotype } & \multicolumn{3}{|c|}{ At 63 DAS } & \multicolumn{3}{|c|}{ At maturity } \\
\hline & \multicolumn{2}{|c|}{ Patancheru } & \multirow{2}{*}{$\begin{array}{l}\text { Hisar } \\
\text { June } \\
\text { sowing }\end{array}$} & \multicolumn{2}{|c|}{ Patancheru } & \multirow{2}{*}{$\begin{array}{l}\text { Hisar } \\
\text { June } \\
\text { sowing }\end{array}$} \\
\hline & $\begin{array}{l}\text { June } \\
\text { sowing }\end{array}$ & $\begin{array}{l}\text { August } \\
\text { sowing }\end{array}$ & & $\begin{array}{l}\text { June } \\
\text { sowing }\end{array}$ & $\begin{array}{l}\text { August } \\
\text { sowing }\end{array}$ & \\
\hline ICPL 4 & $3 \cdot 70$ & 1.54 & $4 \cdot 17$ & $6 \cdot 30$ & $2 \cdot 12$ & $7 \cdot 33$ \\
\hline ICPL 81 & $3: 54$ & 1.67 & 4.63 & 650 & $2 \cdot 77$ & $9 \cdot 29$ \\
\hline ICPL 87 & $3 \cdot 89$ & 1.95 & $5 \cdot 06$ & $8 \cdot 27$ & $3 \cdot 68$ & 11.86 \\
\hline S.E. & $0 \cdot 153$ & $0 \cdot 104$ & 0.335 & 0.200 & 0.205 & 0.064 \\
\hline Mean & $3 \cdot 71$ & 1.72 & $4 \cdot 62$ & $7 \cdot 02$ & $2 \cdot 86$ & $9 \cdot 49$ \\
\hline
\end{tabular}

DAS, days after sowing.

Table 5. Leaf area index of three short-duration pigeonpea genotypes, grown at Patancheru, 1982-3

\begin{tabular}{|c|c|c|c|c|}
\hline \multirow[b]{2}{*}{ Genotype } & \multicolumn{2}{|c|}{ At 63 IAS } & \multicolumn{2}{|c|}{ At maturity } \\
\hline & June sowing & August sowing & June sowing & August sowing \\
\hline ICPL 4 & $3 \cdot 05$ & 1.51 & $1 \cdot 29$ & 0.33 \\
\hline ICPL 81 & $2 \cdot 85$ & $2 \cdot(12$ & 0.75 & 0.59 \\
\hline ICPI 87 & $3 \cdot 49$ & $2 \cdot 92$ & $2 \cdot 25$ & $1 \cdot 70$ \\
\hline S.E. & 0.204 & $0 \cdot 147$ & $(0 \cdot 143$ & 0.095 \\
\hline Mean & $3 \cdot 13$ & $2 \cdot 15$ & 1.43 & $0 \cdot 87$ \\
\hline
\end{tabular}

DAS, days after sowing.

Table 6. Mean seed yields $(t / h a)$ of three short-duration pigeonpea genotypes, 1982-3

\begin{tabular}{ccccc} 
ICPL 4 & ICPL 81 & \multicolumn{1}{c}{ ICPL 87 } & s.E. & Mean \\
\multicolumn{5}{r}{ Patancheru, June sowing } \\
0.15 & 2.51 & 2.21 & 0.053 & $2 \cdot 29$ \\
0.67 & 1.13 & 2.04 & 0.050 & 1.28 \\
3.06 & 0.24 & 0.97 & 0.025 & 0.48 \\
& 3.87 & 5.22 & 0.084 & 4.05 \\
0.94 & 1.05 & 1.31 & 0.055 & 1.10 \\
0.35 & 0.53 & 0.96 & 0.024 & 0.60 \\
1.28 & 1.58 & 2.27 & 0.075 & 1.71
\end{tabular}

Total (single harvest only)

$1 \cdot 97$

$2 \cdot 35$

$2 \cdot 58$

$0 \cdot 197$

$2 \cdot 30$

\section{Sowing date effects}

In the date-of-sowing experiment conducted on the vertisol in $1983-4$, ICPL 81 and ICPL 87 gave maximum first-harvest yields in the June sowing, with yield declining more or less linearly with later sowings (Table 8). The first-harvest yields of ICPL 87 in the June and August sowings of 1983-4 were similar to those obtained on the alfisol in the 1982-3 season (Table 6). However, the yield of ICPL 81 was lower in the June sowing of the 1983-4 season. The total dry matter recorded at first-flush maturity also declined with a delay in sowing date but more steeply than the first harvest yield (Table 8).
The second-harvest yields in this experiment were very low owing to a heavy pod fly (Melanagromyza obtusa) attack. The second-harvest yield declined further at later sowings (Table 8). The total yield of two harvests was significantly greater for the June sowing and for ICPL 87.

Significant sowing date and soil type interactions for the first harvest, second harvest and total yields were observed in genotype ICPL 87 in the 1984-5 season (Fig. 2). The first-harvest yields on alfisol were greatest in the 11 June sowing, with yields declining more or less linearly with later sowings, which were done at 15-day intervals. On the vertisol, a significant decline in yield occurred only between 
Table 7. Harvest index of three short-duration pigeonpea genotypes, 1982-3

\begin{tabular}{lccc} 
& \multicolumn{2}{c}{ Patancheru } & Hisar \\
\cline { 2 - 3 } & June sowing & August sowing & June sowing \\
ICPL 4 & $0 \cdot 38$ & $0 \cdot 43$ & $0 \cdot 28$ \\
ICPL 81 & $0 \cdot 43$ & $0 \cdot 41$ & $0 \cdot 26$ \\
ICPL 87 & $0 \cdot 30$ & $0 \cdot 40$ & $0 \cdot 22$ \\
S.F. & $0 \cdot 010$ & $0 \cdot 020$ & $0 \cdot 014$ \\
Mean & $0 \cdot 37$ & $0 \cdot 42$ & $0 \cdot 25$
\end{tabular}

Table 8. Effect of date of sowing on seed yields $(t / h a)$, total dry matter $(t / h a)$ and harvest index at first harvest of two short-duration pigeonpea genotypes grown on a vertisol at Patancheru, 1983-4

\begin{tabular}{|c|c|c|c|c|c|c|c|}
\hline & \multicolumn{2}{|c|}{ June } & \multicolumn{2}{|c|}{ July } & \multicolumn{2}{|c|}{ August } & \multirow[b]{2}{*}{ S.E. } \\
\hline & ICPL 81 & ICPL 87 & ICPL 81 & ICPI 87 & ICPL 81 & ICPL 87 & \\
\hline First harvest yield & $1 \cdot 62$ & $2 \cdot 21$ & $1 \cdot 35$ & 1.56 & 0.98 & $1 \cdot 00$ & 0.061 \\
\hline Second harvest yield & 0.57 & 0.39 & (6)20 & 0.33 & $0 \cdot 03$ & $0 \cdot 08$ & 0.032 \\
\hline Total yield & $2 \cdot 19$ & $2 \cdot 60$ & 1.55 & 1.90 & $1 \cdot 00$ & 1.09 & 0.085 \\
\hline $\begin{array}{l}\text { Total dry matter } \\
\text { (at first harvest) }\end{array}$ & $5 \cdot 68$ & $5 \cdot 83$ & $3 \cdot 46$ & $3 \cdot 95$ & $2 \cdot 35$ & $1 \cdot 80$ & $0 \cdot 213$ \\
\hline Harvest index & 0.31 & 0.42 & 0.42 & 0.40 & 0.42 & 0.48 & 0.016 \\
\hline
\end{tabular}

S.E. for comparing the genotypes at same level of sowing date are : first harvest: $0 \cdot 050$; second harvest: $0 \cdot 026 ;$ total yield : $0 \cdot 066$; total dry matter: $0 \cdot 205$; and harvest index : $0 \cdot 017$.

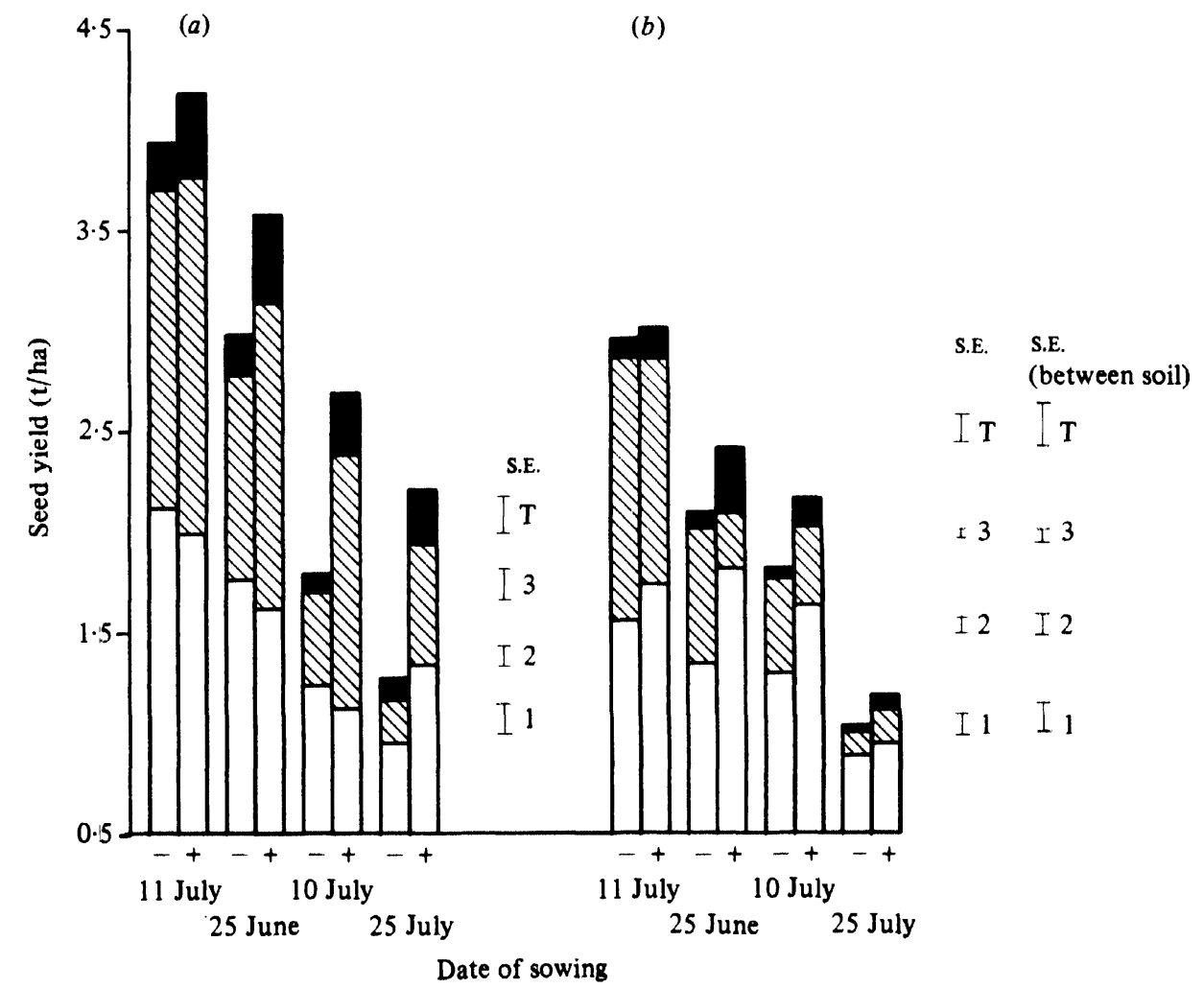

Fig. 2. Yield response of ICPL 87 grown without $(-)$ and with (+) irrigation to four sowing dates on $(a)$ an alfisol and $(b)$ a vertisol, 1984-5. $\square, 1$, First flush yield; $\mathbb{Q}, 2$, second flush yield; $\square, 3$, third flush yield; total bar, T. total yield. 
Table 9. Effect of date of sowing on the yield components of a short-duration pigeonpea genotype ICPL 87 (pooled data of an alfisol and a vertisol) at Patancheru, 1984-5

\begin{tabular}{|c|c|c|c|c|c|}
\hline \multirow[b]{2}{*}{ Yield component } & \multirow[b]{2}{*}{11 .June } & \multicolumn{2}{|c|}{ Date of sowing } & \multirow[b]{2}{*}{$25 . J u l y$} & \multirow[b]{2}{*}{ S.E. } \\
\hline & & 25 June & 10 July & & \\
\hline \multicolumn{6}{|l|}{ No. of pods $/ \mathrm{m}^{2}$} \\
\hline First harvest & 579 & 551 & 461 & 432 & $27 \cdot 2$ \\
\hline Second harvest & 556 & 324 & 277 & 151 & $23 \cdot 7$ \\
\hline Third harvest & 151 & 187 & 118 & 99 & $19 \cdot 9$ \\
\hline \multicolumn{6}{|l|}{ No. of seeds/pod } \\
\hline First harvest & $3: 37$ & $3: 34$ & 358 & $2 \cdot 87$ & $0 \cdot 242$ \\
\hline Second harvest & $2 \cdot 75$ & $2 \cdot 82$ & $2 \cdot 69$ & $2 \cdot 21$ & (0.092 \\
\hline Third harvest & $2 \cdot 20$ & $2 \cdot 28$ & $2 \cdot 36$ & $2 \cdot 11$ & 0.164 \\
\hline \multicolumn{6}{|l|}{100 -seed weight ( $\mathrm{g}$ ) } \\
\hline First harvest & $9 \cdot 88$ & 8.96 & 8.84 & $8 \cdot 63$ & 0.352 \\
\hline Second harvest & $9 \cdot 49$ & $9 \cdot 40$ & $8 \cdot 60$ & 7.97 & 0.243 \\
\hline Third harvest & $7 \cdot 32$ & 6.57 & 5.91 & $5 \cdot 81$ & 0.397 \\
\hline
\end{tabular}

(a)

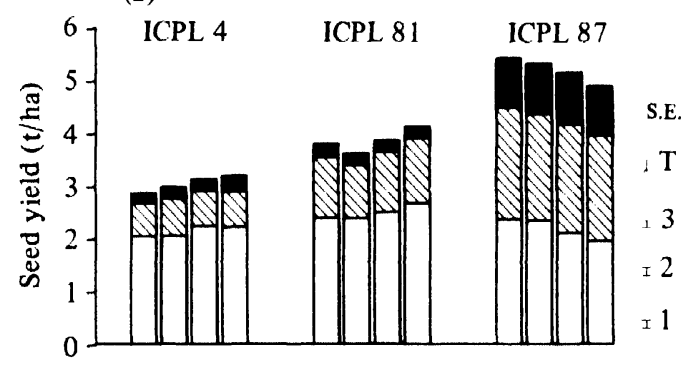

(b)

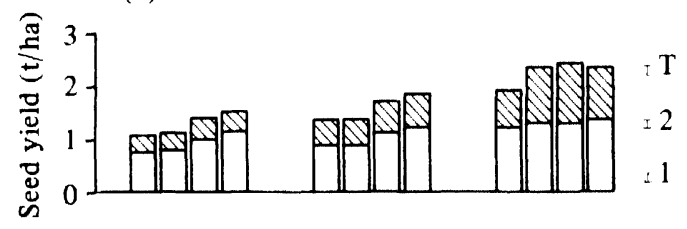

(c)

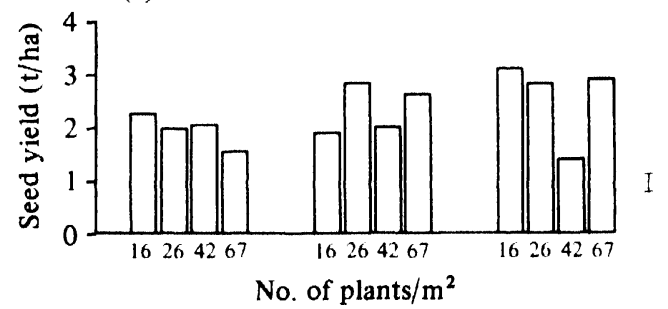

Fig. 3. Yield response of three short-duration genotypes ICPL 4, I('PL 81 and ICPL 87, at four plant population densitien in June $(a)$ and August $(b)$ sowing at Patancheru and June sowing at Hisar (c), 1982-3. $\square, 1$, First flush yield; $\mathbb{Q}, 2$, second flush yield; 3 , third flush yield; total bar, $\mathrm{T}$, total yield.

10 and 25 July. The second-harvest yield on the alfisol, which was significantly greater than on the vertisol, declined less steeply with delayed sowing. This decline in yield in delayed sowings occurred even with irrigation. In fact there was a significant negative response to irrigation in the second-harvest yield on the vertisol. On the alfisol, the response to irrigation was positive in the second harvest. For the third harvest the response to irrigation was positive on both soils. Overall. there was a significant positive response to irrigation in total yield on the alfisol but no response on the vertisol.

We also studied the relationship of total dry matter at first-flush maturity (in different experiments and different sowings) with the number of days to maturity, mean daily temperature prevailing during the crop growth period and growing degree days (obtained by multiplying growth duration by the differences between mean daily temperature and base temperature). The relationship was highly significant only for daily mean temperatures $(r=0.91$, $n=11)$ and growing degree days $(r=0 \cdot 75, n=11)$.

The yield component that declined most because of delayed sowing was the number of $\operatorname{pods} / \mathrm{m}^{2}$, followed by the 100-seed weight and number of seeds per pod (Table 9). A similar pattern of decline in these three components was observed from the first to the third harvest.

\section{Spacing effects}

In the June sowing at Patancheru in 1982-3, the main effect of spacing was not significant but the genotype $\times$ spacing interaction was (Fig. 3). ICPL 4 and ICPI, 81 gave higher first-harvest yields at higher densities $\left(42-67\right.$ plants $\left./ \mathrm{m}^{2}\right)$ and ICPL 87 gave higher yields at lower densities (16-26 plants/ $\mathrm{m}^{2}$ ). The second-harvest yield was less affected by plant population density. At the third harvest, yields were similar at all spacings, except for ICPL 4 . About $45 \%$ of the plants of this genotype had died by third-Hush maturity, compared with $32 \%$ in ICPL 81 and $6 \%$ in ICPL 87 . The total yield responded in a manner similar to the first- 


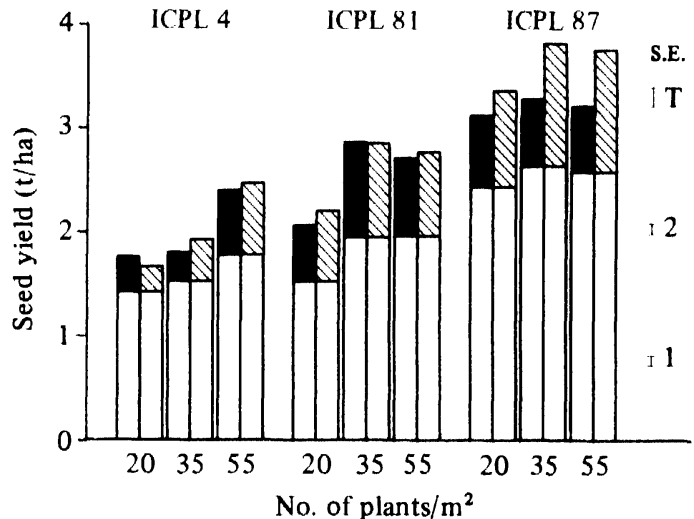

Fig. 4. Yield response of three short-duration genotypes, ICPL, 4, ICPI, 81 and IC PL 87, at three plant population densities on an alfisol, Patancheru, 1983-4. $\square$, 1. First flush yield with no irrigation: $\mathbb{Q}, 2$, second flush yield with irrigation: 2, second Hush yield with no irrigation; total bar, $T$, total yield.

harvest yield. In the August sowing. the firstharvest, second-harvest and total yields were greatest at the densest plantings for all genotypes. At Hisar there was no clear effect of plant population density on yield.
On the vertisol in 1983 4, the response of ICPL 81 and ICPL 87 to spacing was similar to that on alfisol and interaction between sowing date and plant popliation density was not significant. Therefore, the results of response to spacing on only the alfisol are presented (Fig. 4). The mean first-harvest yield was $1.58 \mathrm{t} / \mathrm{ha}$ for ICPL $4,1.82 \mathrm{t} / \mathrm{ha}$ for ICPL 81 and $2.56 \mathrm{t} / \mathrm{ha}$ for ICPL 87 , the differences being significant. The first-harvest yield of ICPL 4 increased as density increased from 20 to 55 plants $/ \mathrm{m}^{2}$, but yields of ICPL 81 and ICPL 87 increased only up to 35 plants $/ \mathrm{m}^{2}$. The yield at 55 plants $/ \mathrm{m}^{2}$ did not differ significantly from yield at 35 plants $/ \mathrm{m}^{2}$ in the latter two genotypes. The pattern for the secondharvest and total yield was similar to that observed for the first harvest.

Irrigation applied during the second flush increased the yield of ICPL 87 only. The secondharvest yields in general were lower compared with other seasons. There was over $40 \%$ pod fly damage, and this could be the reason for the lower yields. ICPL 87 yielded $1 \cdot 1 \mathrm{t} / \mathrm{ha}$ with irrigation and $0.73 \mathrm{t} / \mathrm{ha}$ without irrigation. The second-harvest yields of ICPL 81 were similar to those of ICPL 87 when not irrigated, whereas with irrigation ICPL 87 gave significantly higher yields. The yield of ICPL 4
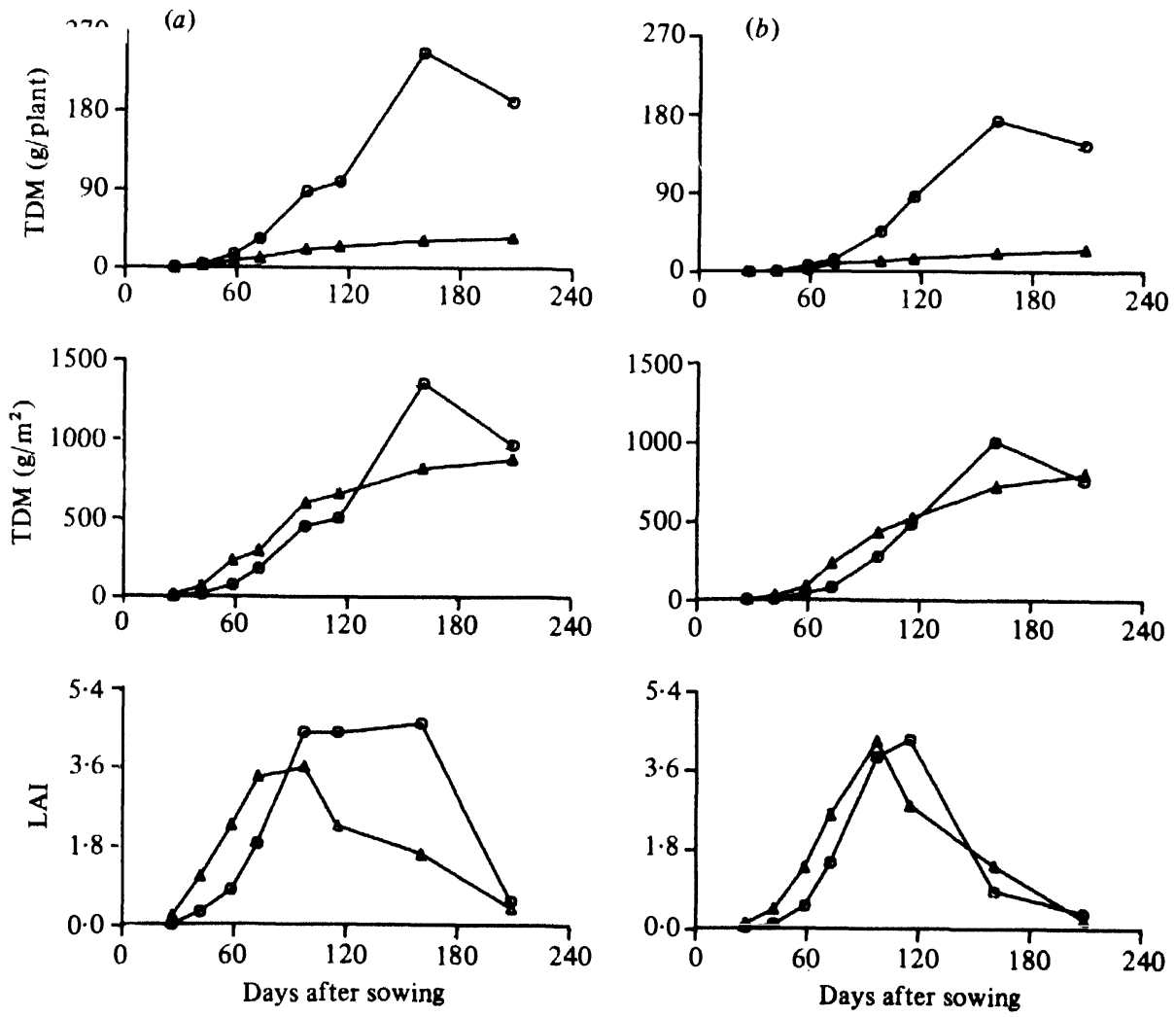

Fig. 5. Total dry matter (TDM) and leaf area index (LAI) accumulation in a short-duration genotype ICPL 87 $(\triangle)$ and a medium-duration genotype $\mathrm{BINN} 1(\mathrm{O})$ on $(a)$ an alfisol and $(b)$ a vertisol, Patancheru, 1984 5. 
Table 10. Comparison of phenology, seed yield and total dry matter of a short-duration (ICPL 87) with a medium-duration $(B I) N$ 1) pigeonpea genotype gromen at Patancheru, 1984-5

\begin{tabular}{|c|c|c|c|c|c|}
\hline & & & & 87 & \\
\hline & Alfinol & Vertisol & Alfisol & Vertisol & S. $\boldsymbol{F}$. \\
\hline 1)ays to $50 \%$ flowering & $11: 3$ & 127 & 79 & 78 & $\mathrm{NA}$ \\
\hline Day's to first-flush maturity & $18: 3$ & 180 & $1: 3$ & $1: 2$ & N.I \\
\hline Days to second-flush maturity & & & 197 & 196 & NA \\
\hline First-harvest yield (1/ha) & $2 \cdot 34$ & $2 \cdot 40$ & $2 \cdot 38$ & $1 \cdot 79$ & $\mathrm{NA}$ \\
\hline Second-harvest yield ( $t / h a)$ & & & 1.71 & $1 \cdot 36$ & NA \\
\hline Total yjeld (1/ha) & $2 \cdot 34$ & $2+40$ & $4 \cdot 119$ & $3 \cdot 15$ & $0 \cdot 106 i$ \\
\hline Yield ( $\mathrm{kg} / \mathrm{ha}$ per day) first harvest & $1 \cdot 2 \cdot 8$ & $13 \cdot 2$ & $19 \cdot 4$ & $14 \cdot 7$ & $\mathrm{NA}$ \\
\hline $\begin{array}{l}\text { Yield ( } \mathrm{kg} / \mathrm{ha} \text { per day) first and } \\
\text { serond harvest }\end{array}$ & & 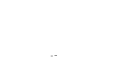 & $201 \cdot 8$ & $16 \cdot 1$ & Nit \\
\hline Total dry matter (t/ha) & $9 \cdot 69$ & $7 \cdot 64$ & $8 \cdot 70$ & $x \cdot(1)=2$ & $(1) \cdot 341$ \\
\hline Harvest index (for total yield) & 0.24 & $(1) \cdot 31$ & $0 \cdot 47$ & $0 \cdot 39$ & $(1) \cdot(1) 1$ \\
\hline
\end{tabular}

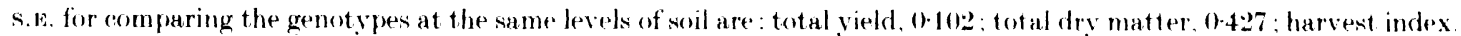
(1) 1). NA, Not analysed.

was the lowest of all the genotypes, with and without irrigation. The total of two Hush vields was greatest for IC PI, 87, $3.7 \mathrm{t} /$ ha with irrigation given during the second flush, and $3.4 \mathrm{t} /$ ha without irrigation.

\section{Comparative productivity of IC $P L$ L 87 and $B I) N 1$}

ICPL 87 attained greater growth rates than BION 1 in the initial stages even though the growth of individual plants was initially similar (Fig. 5). The higher dry-matter accumulation $/ \mathrm{m}^{2}$ of ICPL 87 in the initial stages was probably due to the higher plant population density at which it was grown, compared with BIDN 1. Development of the leaf area index was also faster in ICYPL 87 for this reason (Fig. 5). (On both soils, ICI'I, 87 attained a maximum leaf area index of 34 by 125 IDAS.

The total yield from two harvests of ICPI, 87 was $4 \cdot 09 \mathrm{t} / \mathrm{ha}$ on the alfisol and $3 \cdot 15 \mathrm{t}$ / ha on the vertisol. This was significantly higher than BDN 1, which gave $2 \cdot 34 \mathrm{t}$ /ha on the alfisol and $2.40 \mathrm{t} / \mathrm{ha}$ on the vertisol in one harvest (Table 10). Productivity per day was also higher in ICPI, 87. The total dry matter yield of ICPI 87 was about $90 \%$ of BI)N 1 on the alfisol, while on the vertisol it was slightly higher than that of BION 1. The harvest index. calculated on the basis of yields obtained in similar periods, ranged from 39 to $47 \%$ for ICPL 87 and from 24 to $31 \%$ for BDN 1 in two soils.

\section{DISCUSSION}

The Hisar location in northern India, being at a higher latitude than Patancheru, has longer photoperiods, from the longest day in June (when pigeonpea is usually sown) to the September equinox. Further, mean daily temperatures during the above growing period are 4-5 $\mathrm{O}$, higher at Hisar than at Patancheru. Since both shorter photoperiods and moderate temperatures (25-30 $\left.0^{\circ}\right)$ induce early flowering in pigeonpea (McPherson, Warrington : Turnbull, 1985), it was not surprising that all thres genotypes flowered and matured about 1 month earlier at Patancheru than at Hisar. This shortei crop growth duration at Patancheru eould have contributed to the lower growth and dry-matter production of all three genotypes there. Further. owing to the responsiveness of pigeonpea growth to high temperatures (McPherson et al. 1985) : Sheldrake, 1984), a $45^{\circ}$ ( : lower temperature during the rainy season at Patancheru might have also contributed to the decreased dry-matter production at this location. Perhaps the decline in dry-matter production with delayed sowing at Patancheru may also be one of the major factors responsible for yicld decline with delayed sowing, particularly since phenological differences between different nowings were not very large.

Although there were growth differences at Hisar and Patancheru, the yields were similar, at about $2.3 \mathrm{t}$ /ha for the June sowing, mainly because of the higher harvest index at I'atancheru. The environmental conditions that control the partitioning of the dry matter in pigeonpea are not precisely known. In soya bean, continuous short-day photoperiods after flowering have been reported to increase the dry-matter accumulation in pods at the expense of vegetative tissues (Thomas \& Raper. 1976). At Patancheru, a further improvement in harvest index of all genotypes was observed when sowings were delayed, but it was not sufficient to offset the decline in total dry matter and, therefore vield declined. Thus, it may not be desirable to sow these genotypes late, to avoid the rains, which are suspected of interfering with the pod formation (Sharma, Saxena \& Green, 1978) during the reproductive phase. Further, the seed size may also decline with delayed sowing. 
Spence \& Williams (1972) have emphasized that a reduction in plant size of pigeonpea due to inductive thermo-photoperiods can be compensated for by increasing plant density. In the present experiment, the responsiveness of pigeonpea to dense sowing appeared to increase in the order: at Hisar, in the June sowing at Patancheru, and in the August sowing at Patancheru. However, delayed sowing caused such a severe reduction in total dry matter that even a very high density of 66 plants $/ \mathrm{m}^{2}$ could not fully offset the decline in the single plant yield. ICPL 87 responded to spacing somewhat differently from the other two genotypes in the June sowing at Patancheru. A density of $25-35$ plants $/ \mathrm{m}^{2}$ appeared optimal for this genotype. The lower optimum plant density of this genotype may be due to its slightly longer duration and greater dry-matter production. The optimum density for this genotype was 5-7 times higher than considered optimum for mediumduration genotypes grown in peninsular India (Rao, Venkataratnam \& Sheldrake, 1981). In three seasons, ICPL 87 gave over $2 \mathrm{t} /$ ha in the first harvest, which is much higher than the yields reported earlier (about $0.6 \mathrm{t} / \mathrm{ha}$ ) of other short-duration pigeonpea genotypes, which were grown at a density of 8 plants $/ \mathrm{m}^{2}$ in peninsular India (Sharma et al. 1978).

Pigeonpea is intrinsically a perennial plant. After the first harvest the warm winter weather at Patancheru permitted up to two additional harvestings from all the three short-duration genotypes, ICPL 4, ICPL 81 and ICPL 87. At Hisar, the subsequent weather during winter becomes too cool for the growth and survival of pigeonpea so multiple harvests were not attempted. At Patancheru, even among the limited genotypes tested there were significant genotypic differences in the second-and third-harvest yields, suggesting the possibility of selecting genotypes particularly suited to multiple harvesting. ICPL 87 had better second- and thirdharvest yield potential than ICPL 4 and ICPL 81 which may be related to its higher leaf area retention at first-flush maturity. It may also be that this genotype is more perennial than the other genotypes tested. Owing to a good multiple-harvest potential, ICPL 87 gave as much as $5.2 \mathrm{t} / \mathrm{ha}$ in the 1982-3 season, $3 \cdot 6 \mathrm{t} / \mathrm{ha}$ in the $1983-4$ season and $4 \cdot 1 \mathrm{t} / \mathrm{ha}$ in the 1984-5 season. These yields are far higher than those of medium-duration pigeonpea cultivars grown in the Patancheru environment. In a com. parison of productivity, ICPL 87 outyielded BDN 1, a redium-duration genotype of pigeonpea, by producing two harvests compared with the one of the latter over a similar period. Further, the shorter duration of ICPI 87 allowed more plants to be used per unit area, resulting in higher initial crop growth rates and quicker canopy development than for BDN 1, both of which are considered important for the monoculture of pigeonpea (Willey et al. 1981).

The multiple-harvest potential, particularly of ICPL 87, appeared better on the alfisol than on the vertisol, both with and without irrigation. This was rather unexpected, at least without irrigation and at the delayed sowings, since vertisols have a much higher water-holding capacity than alfisols. With irrigation, the second-harvest yield significantly increased on the alfisol whereas on the vertisol, no such yield increases were observed. Difference in the second-harvest yield therefore became even more pronounced between the two soils. A similar observation has been made by Venkataratnam \& Sheldrake (1985) for the second-harvest yield of mediumduration genotypes. The exact reasons for this are not known. Whether biological nitrogen fixation, which is generally poorer on vertisols than on alfisols (Kumar Rao et al. 1981), is a limiting factor for the second-and the third-harvest yield on vertisols is being presently examined.

The potential for multiple harvests of pigeonpea has recently been confirmed in the lowland tropical region (Tayo, 1985), using a different genotype. Although the results reported here on the potential of short-duration pigeonpea for multiple harvests are from one location, the practical feasibility of multiple harvests has been confirmed in large demonstrations conducted in farmers' fields at other locations in peninsular and central India using ICPL 87. It is therefore expected that such a system should be feasible in areas where winters are mild (e.g. minimum temperatures above $10^{\circ} \mathrm{C}$ ).

\section{REFERENCES}

Green, J. M., Sharma, D., Reddy, L. J., Saxena, K. B., Gupta, S. C., Jain, K. C., Reddy, B. V. S. \& RAO, M. R. (1981). Methodology and progress in the ICRISAT pigeonpea breeding program. In Proceedings of the International Workshop on Pigeonpeas, vol. 1, pp. 437449. Patancheru, A. P., India: International Crops Research Institute for the Semi-Arid Tropics.

Kanwar, J. S. (1981). Early-maturing pigeonpeas heading for a green revolution. International Pigeonpea Newsletter 1, 6-7.

Kumar RaO, J. V. D. K., DART, P. J., DAY, J.M. \&
Matsumoto, T. (1981). Nitrogen fixation by pigeonpea. In Proceedings of the International Workshop on Pigeonpeas, vol. 1, pp. 190-199. Patancheru, A. P. India: International Crops Research Institute for the SemiArid Tropies.

McPherson, H. G., Warkington, I. J. \& Turnbull, H. L. (1985). The effect of temperature on rate of development of pigeonpea. Annals of Botany 56, 597-611.

RaO, I. M., Venkataratnam, N. \& Sheldrake, A. R. (1981). Response to row to row and plant to plant spacing in pigeonpea. In Proceedings of the International 
Workshop on Pigeonpeas, vol. 2, pp. 249-256. Patancheru, A. P., India : International Crops Research Institute for the Semi-Arid Tropies.

SaXena, M. C. \& Yadav, D. S. (1975). Some agronomic considerations of pigeonpeas and chickpeas. In International Workshop on Grain Legumes, pp. 31-61. Hyderabad, A. P. India: International Crops Research Institute for the Semi-Arid Tropics.

Sharma, D., Saxena, K. B. \& (Gheen, J. M. (1978). Potential for ratooning in pigeonped. Field Crops Research 1, 165-172.

Sheldrake, A. R. (1984). Pigeonpea. In The Physiology of Tropical Field Crops (ed. P. R. Goldsworthy and N. M. Fisher), pp. 385-417. Chichester, U.K.: Academic Press.

Spence, J. A. \& Williams, J. A. (1972). Use of photoperiod response to change the plant design. Crop Science 12, 121-122.

Tayo, T. O. (1985). Assessment of the effect of ratooning pigeonpea (Cajanus cajan (L.) Millsp.) in the lowland tropies. Journal of Agricultural Science, Cambridge 104, 589-593.

Thomas, J. F. \& Raper, C. D. JR. (1976). Photoperiodic control of seed filling for soybeans. Crop Science 16, $667-672$.

Venkataratnam, N. \& Shelidrake, A. R. (1985). Second harvest yields of medium-duration pigeonpeas (Cajanus cajan) in peninsular India. Field Crops Research 10, 323-332.

Wallis, E. S., Byth, D. E. Winteman, P. ( $\&$ \& Saxena, K. B. (1983). Adaptation of pigeonpea (Cajanus cajan) to mechanised culture. In Proceedings of Australian Plant Breeding ('onference, pp. 142-145. Adelaide, Australia: Australian Plant Breeding Society.

Willey, R. W., RaO, M. R. \& Natarajan, M. (1981). Traditional cropping systems with pigeonpea and their improvement. In Proceedings of the International Workshop on Pigeonpeas vol. 1, pp. 11-25. Patancheru, A. P., India: International ('rops Research Institute for the Semi-Arid Tropies. 